\title{
Partitions, Compartments and Portals: Cave Development in internally impounded karst masses
}

\author{
R. Armstrong L. Osborne ${ }^{1}$
}

SPELEOGENESIS

Re-published from: Speleogenesis and Evolution of Karst Aquifers 1 (4), www.speleogenesis.info, 12 pages (ISSN 1814-294X).

\section{Abstract:}

Osborne, R. A. L. 2005. Partitions, Compartments and Portals: Cave Development in internally impounded karst masses. International Journal of Speleology, 34 (1-2), 71-81. Bologna (Italy). ISSN 0392-6672.

Dykes and other vertical bodies can act as aquicludes within bodies of karst rock. These partitions separate isolated bodies of soluble rock called compartments. Speleogenetically each compartment will behave as a small impounded-karst until the partition becomes breached. Breaches through partitions, portals, allow water, air and biota including humans to pass between sections of caves that were originally isolated.

Keywords: impounded karst, speleogenesis in steeply dipping limestones, Australia.

Received 4 June 2005; Revised 8 June 2005; Accepted 14 June 2005.

\section{INTRODUCTION}

It has been long recognised that bodies of karst rock may be impounded by surrounding insoluble rocks and/or confined by overlying aquicludes. On a smaller scale, planar bodies of insoluble rock, such as dykes, or geological structures such as faults, may act as aquicludes (partitions) within a mass of karst rock. Where swarms of dykes intrude a karst rock mass along sets of intersecting joints (or in the case of an impounded karst along parallel joints) each mass of dyke-surrounded karst rock effectively becomes a small impounded-karst (compartment) (Fig. 1).

In narrow, steeply dipping limestone masses such as the impounded karsts of eastern Australia (Osborne, 1999a) and the stripe karsts of Scandinavia (Lauritzen, 2001) such aquicludes should effectively prevent speleogenesis along strike. One might expect that such conditions would be unfavorable for the development of caves. In New South Wales, Australia, however these conditions occur in five significant cavernous karsts: Bungonia ("A" in Fig. 2), Colong ("B" in Fig. 2), Jenolan ("C" in Fig. 2), Walli ("D" in Fig. 2) and Wombeyan ("E" in Fig. 2). Lannigan's Cave at Colong, one of the most extensive and complex caves

1- School of Development and Learning, A35

University of Sydney, NSW, 2006 Australia.

E-mail:a.osborne@edfac.usyd.au

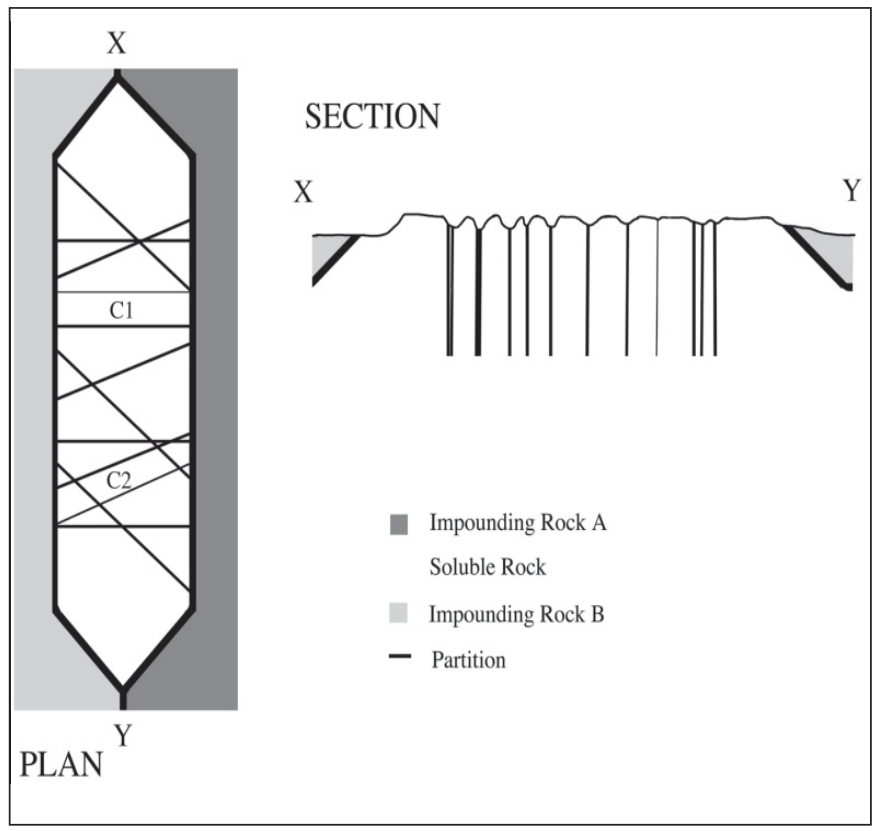

Fig. 1. Diagrammatic representation of an elongate impounded karst partitioned by dykes. $\mathrm{C} 1=$ compartment bounded on 2 sides by partitions and on 2 sides by the boundaries of the limestone; $\mathrm{C} 2$ = compartment bounded on 4 sides by oblique partitions.

in the State, has developed under these conditions. A somewhat similar phenomenon has been described by Klimchouk et al. (1995) in the great gypsum caves of the western Ukraine. 


\section{PARTITIONS}

Partitions are narrow, vertical or near vertical, planar insoluble rock masses or structures that act as aquicludes within karst rock masses. Six types of partitions have so far been recognised:

- Igneous dykes

- Palaeokarst volcaniclastic dykes

- Insoluble beds

- Dolomitic palaeokarst

- Filled joints

- Faults

The concept of partitions is an extension and refinement of the ideas of dykes "controlling cave development" discussed by Osborne (1985), of "paleokarst as aquicludes" described by Osborne (1993 c; 1999b, 2000) and of "pre-speleogenetic joints" described by Klimchouk et al. (1995).

\section{Igneous Dykes as Partitions}

Basic igneous dykes oriented perpendicularly or obliquely to strike are not uncommon in the impounded Palaeozoic karsts of eastern Australia. The dykes are generally one metre or less in thickness and may occur individually or in swarms. Often dykes exposed in caves in close proximity to the ground surface, are not found to crop out at the surface (Osborne, 2001a).

Osborne (1985) recognised the significance of basic dykes for cave development in eastern Australia by noting that distinct changes in morphology of Lannigan's Cave at Colong coincided with the cave intersecting dykes. Igneous dykes acting as partitions were described, although not named as such, from Bungonia Caves by Osborne (2001a). Halls, elongate tubular voids with blind ends, were observed to terminate on encountering dykes oriented perpendicular to strike. These relationships are well illustrated in Flying Fortress Cave (Fig. 3).

Igneous dyke partitions also occur in Jenolan Caves. In Spider Cave the entrance passage follows an east-west striking basic dyke. Further inside the cave, the same dyke is breached by a passage roughly perpendicular to the dyke. The Jenolan Underground River flows through this passage.

Lannigan's Cave at Colong is developed along strike in a thin body of steeply dipping Silurian limestone that is intersected by numerous basic dykes (Fig. 4). Most of the dykes are oriented perpendicular to strike, but some run oblique to strike. Most compartments in the Colong rock mass are bounded by partitions on two sides and by the lateral boundaries of the limestone on the other two sides (similar to C1 in Fig. 1). Some compartments at Colong, however, are bounded on all four sides by dykes (similar to C2 in Fig. 1).

The development of Lannigan's Cave along strike presents a significant speleogenetic problem, which will be discussed further in this paper. How could such a cave develop along strike in a body of limestone with so many hydrological barriers blocking the way?

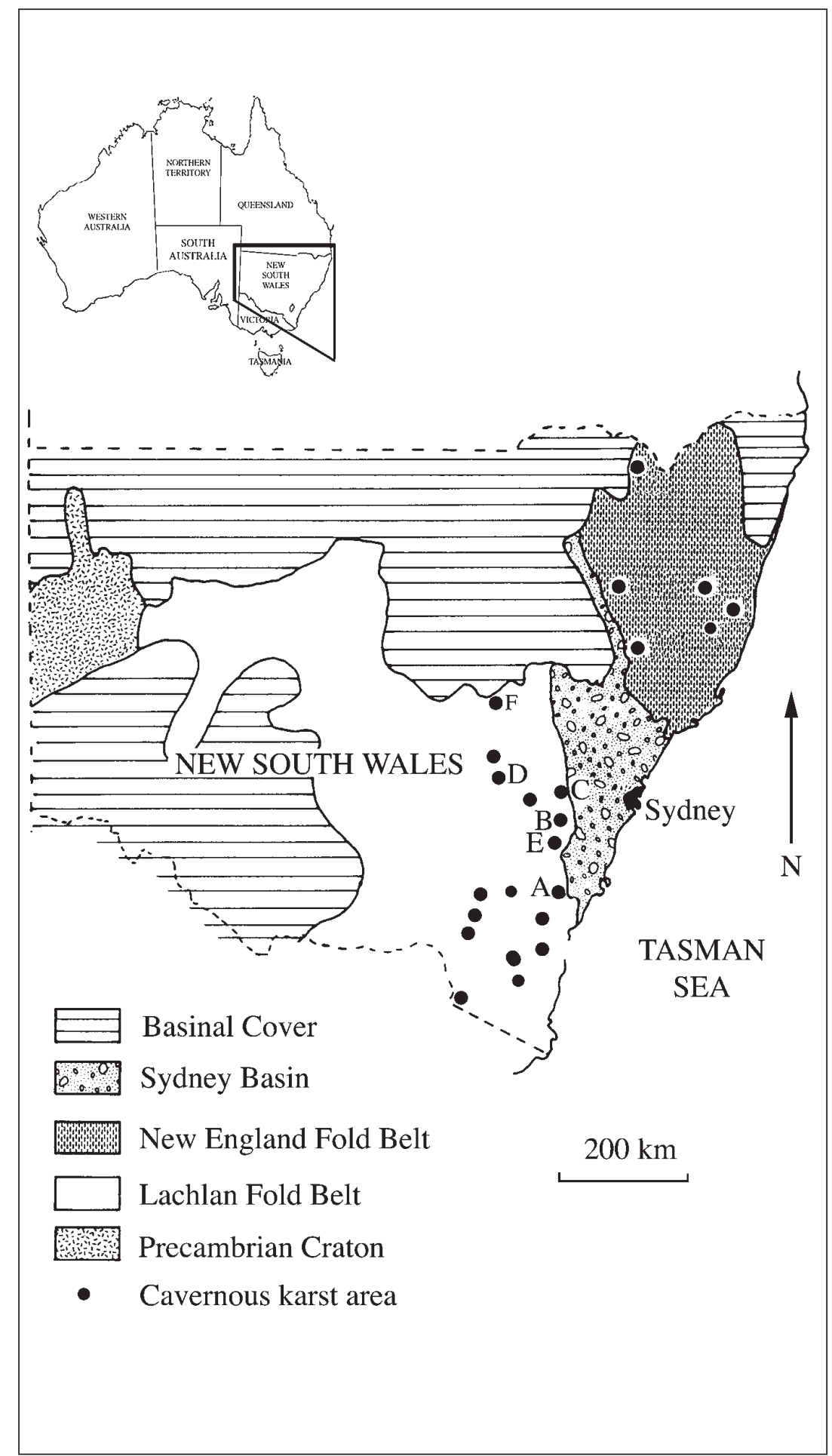

Fig. 2. Eastern Australia showing locations discussed:

$\mathrm{A}=$ Bungonia; $\mathrm{B}=$ Colong; $\mathrm{C}=$ Jenolan; $\mathrm{D}=$ Walli; $\mathrm{E}=$ Wombeyan; $\mathrm{F}=$ Wellington. 


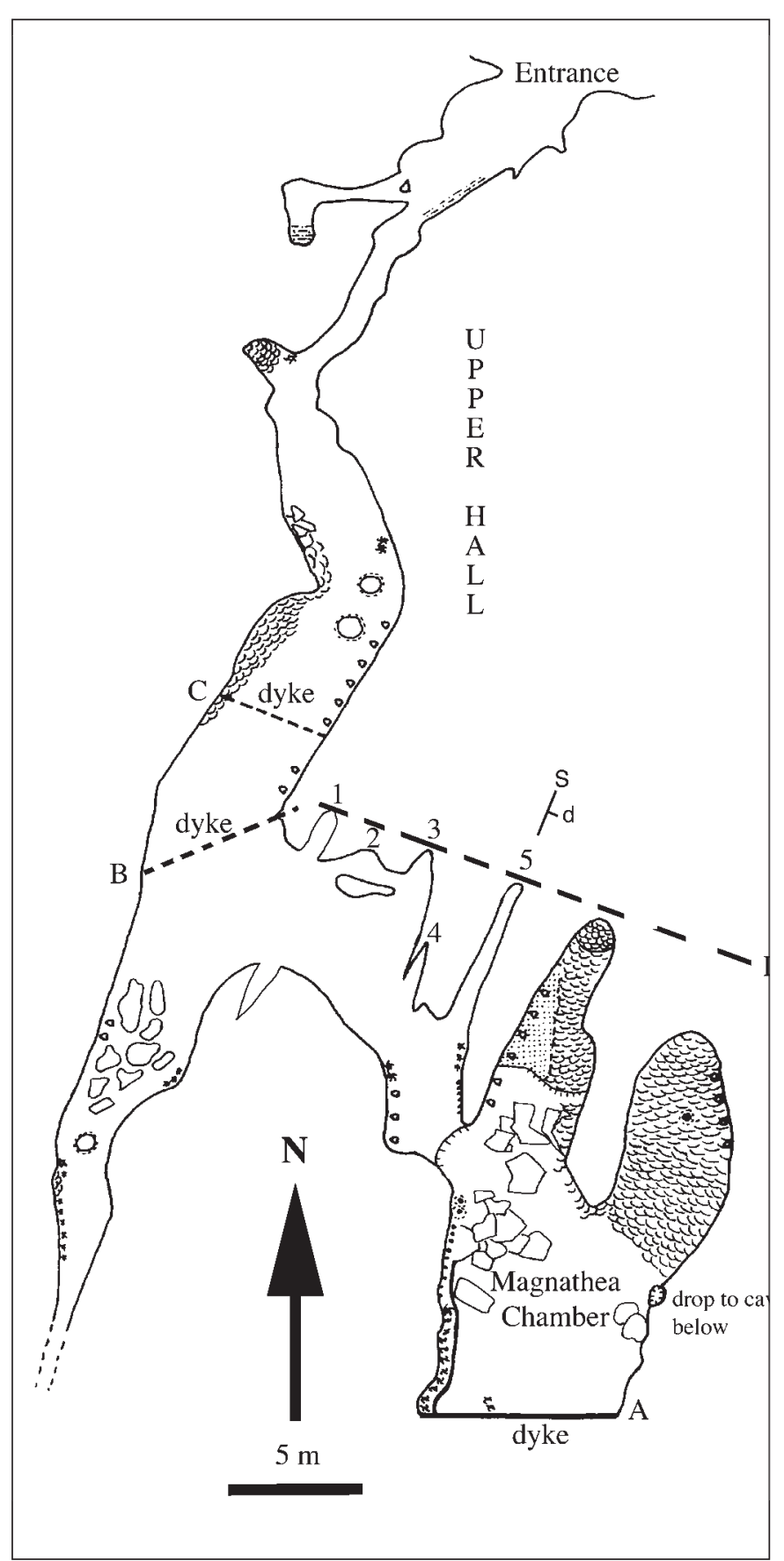

Fig. 3. Flying Fortress Cave, Bungonia, after Osborne (2001), based on map from Bauer and Bauer (1998). Note: Termination of Magnathea Chamber by dyke "A" at southern end. Small dykes "B" and " $\mathrm{C}$ " that have been completely breached by Upper Hall. These dykes are now largely altered to calcite, see Fig. 5 . Termination of small halls $1,3 \& 5$ by dyke "D".

\section{Alteration of Dykes}

Specimens of dyke rocks, forming partitions, have been collected from a number of localities in Bungonia, Colong and Jenolan Caves. In all cases the rocks were extensively altered and/or weathered.

Frequently the dyke rocks are completely or partially replaced by calcium carbonate (Fig. 5). In other cases they have been converted into a ferruginous boxwork with a 'ghost' igneous texture visible at low power, while vesicles and some larger crystals have been

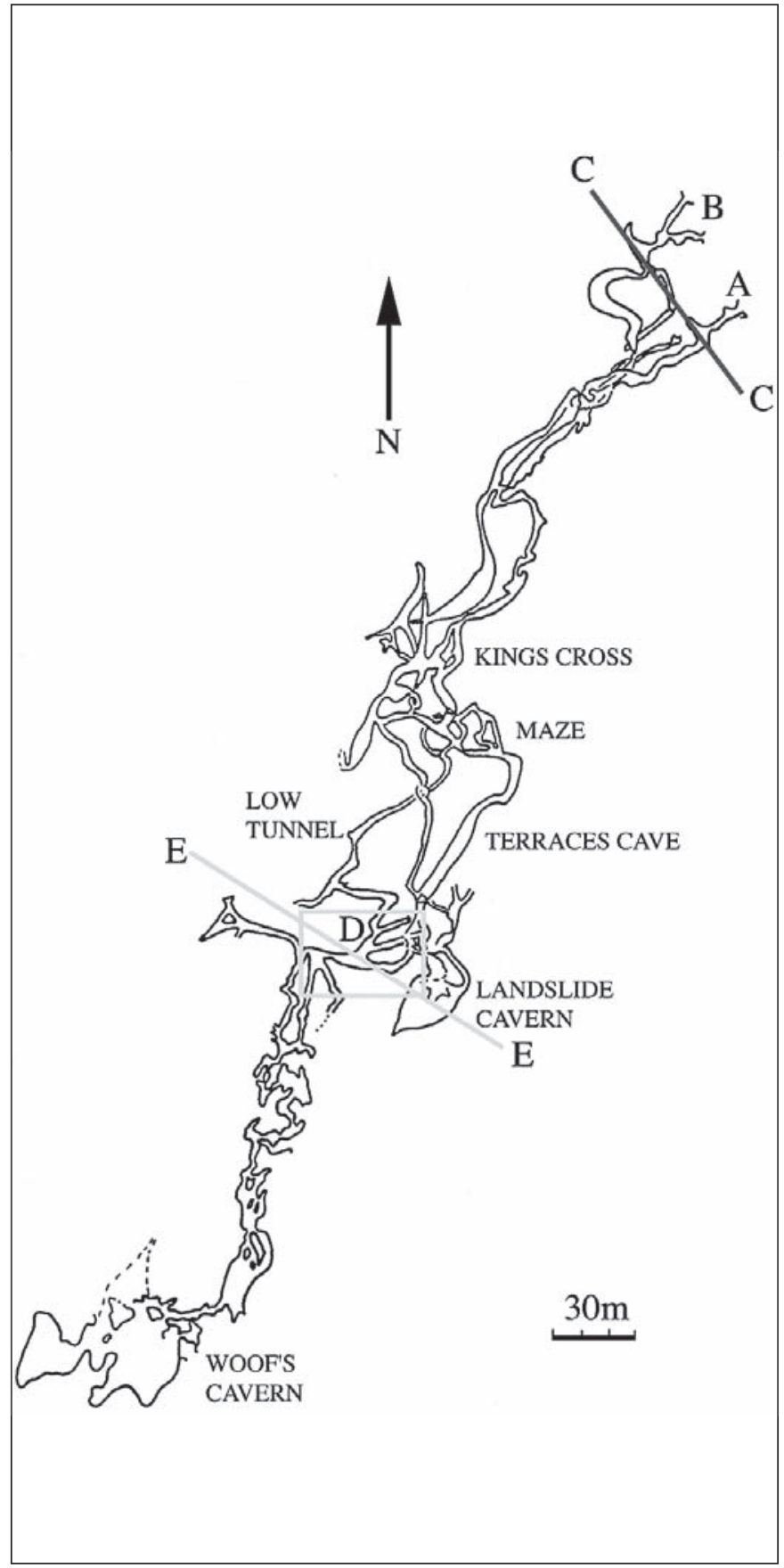

Fig. 4. Lannigan's Cave, Colong, simplified map based on compilation by M.G. Hooppell. Ongoing mapping by A Pryke has shown that the southern section of the cave (south of E-E) is far more extensive and complex than had been previously appreciated. $A=$ Upper Entrance; $B$ - Lower Entrances; $C=E-W$ rift near entrance; $D=$ Amber Cave region, for detail see Fig. 14; $E$ = Main dyke, breached by portal at Amber Cave divides cave into complex network cave to south and a more simple northern section dominated by north-south trending passages.

replaced by chalcedony. Limonite pseudomorphs after pyrite are common in both styles of alteration.

Viewed under crossed nicols at $10 \mathrm{x}$ with a tint plate. Pyroxene phenocryst (upper right) is now a calcite pseudomorph and plagioclase laths are also now calcite pseudomorphs.

Matrix is altered to micritic calcite and shows zoned extinction. Groundmass in right $2 / 3$ of image is at extinction. 


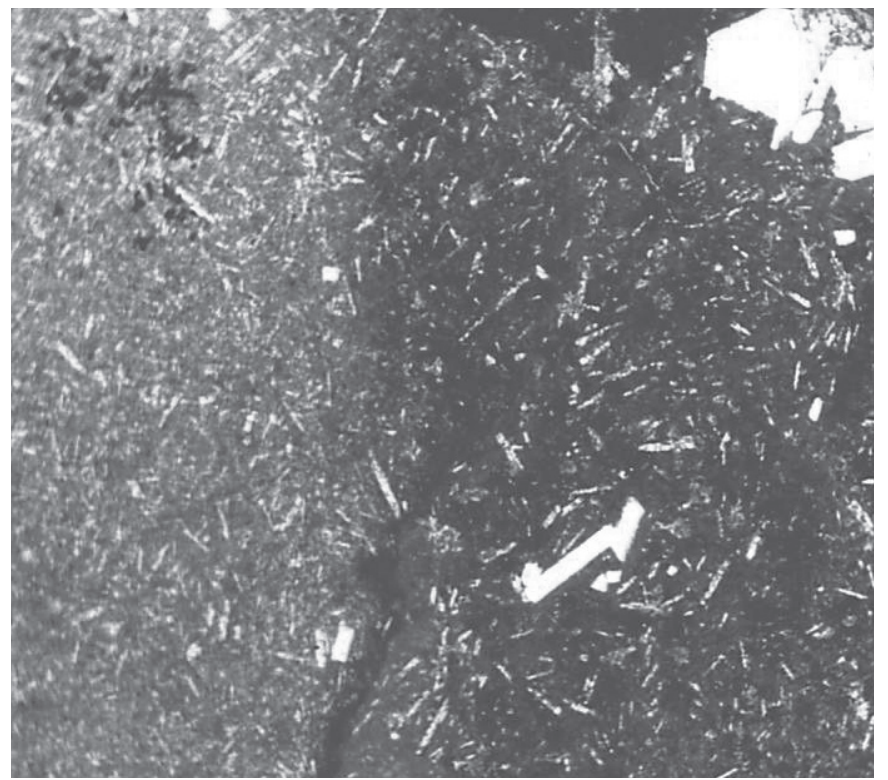

Fig. 5. Thin-section of dyke rock showing a doleritic texture that has been completely replaced by calcite. Sample is from Flying Fortress Cave, Bungonia from the dyke marked "B" in Fig. 3.

\section{Total Removal of Dykes}

The northern section of Lannigan's Cave at Colong (Fig. 4) is largely developed along a north-south axis. Narrow, east-west trending rifts intersect the northsouth trending passages. These rifts appear to result from the complete removal of a dyke from within the surrounding bedrock as a result of weathering and erosion. One example of this is the structure C-C in Fig. 4. This narrow rift partially connects and guides across-strike cave development at three different levels in the cave. Osborne (1985) illustrated the survival of a remnant of dyke rock in another of these rift-shaped voids.

Igneous dykes, along with other structures that form partitions can under different conditions and circumstances act as aquifers and conduits, particularly when their removal produces an open void in the bedrock.

\section{Paleokarst Volcaniclastic Dykes as Partitions}

At Wombeyan Caves ("E" in Fig. 2), massive marble is crossed by joints filled with volcaniclastics similar to those of the overlying Bindook Porphyry Complex. Osborne (1993b) interpreted these filled joints as palaeokarst features resulting from grikes in a karstified surface being filled by tephra from an erupting volcano.

These volcaniclastic dykes are on occasions intersected by caves. Thin dykes $<50 \mathrm{~mm}$ thick are directly penetrated by cave passages and are exposed in cross-section in the cave walls. Interaction between cave passages and thicker dykes is much less common and more complex.

Sigma Cave at Wombeyan (Fig. 6) intersects four thick Northwest to Southeast trending dykes. One dyke ("A" in Fig. 6, Fig. 7) remains reasonably intact, except where it is breached by a small portal. This dyke separates cave voids with distinctly different morphologies. To the north of the dyke the cave is a north-south trending semicircular tube with a low ceiling, south of the dyke the cave ceiling is considerably higher.

In the vicinity of Knockers Cavern Two Sigma Cave intersects three Northwest to Southeast trending dykes. The northernmost dyke forms a partial barrier ("The Gates" "C" in Fig. 6) across the stream canyon at the northern end of the chamber. The central dyke ("D" in Fig. 6) is associated with an east-west trending rift in the cave ceiling, marking a zone of intense solution, while the southernmost dyke ("E" in Fig. 6) marks the southern termination of the chamber. The cave south of Knockers Cavern Two is only accessible through a small portal in the southernmost dyke.

\section{Insoluble Beds as Partitions}

At Walli Caves ("D" in Fig. 2), caves with Hall and Narrows morphology are developed in moderately dipping (63 degrees) massive Ordovician limestone (The Belubula Limestone of the Cliefden Caves Limestone Group, Webby \& Packham, 1982). Deep Hole, one of the largest caves at Walli (Fig. 8) is principally guided by joints oriented perpendicular to bedding. Two major halls ("A" and "B" in Fig. 8) terminate abruptly at a siltstone bed. One hall " $A$ " shows no change in its width (in limestone) towards its termination, while the other "B" widens and has a large cupola developed in its ceiling. This partition remains intact.

\section{Dolomitic Palaeokarst as Partitions}

Osborne (1993c, 1999b, 2000) described how bodies of dolomitic palaeokarst at Jenolan Caves had inhibited phreatic cave development, but had failed as a consequence of vadose weathering and now formed constrictions (duck-unders), rather than blockages in the path of the Jenolan Underground River (Fig. 9). Applying the nomenclature developed here the palaeokarst body would be considered a "partition" and the constricted opening through which the stream now flows (the duck-under) a "portal".

\section{Filled joints as Partitions}

Klimchouk et al. (1995) described vertical joint fillings that protrude into cave passages, but do not alter the morphology of cave passages on either side of them, in the gypsum caves of the western Ukraine. These fillings (Fig. 10) are quite thin, but remnants remain long after they have failed as partitions.

\section{Faults as Partitions}

While many of the impounded karsts of eastern Australia have a narrow, elongate outcrop pattern, as described by Osborne (1999a), other cavernous karsts such as Cliefden and Walli have much more complex outcrop patterns, often related to folding.

In these karsts the cavernous strata are frequently partitioned by faults striking perpendicular, oblique and in some cases parallel to bedding. These strata are laterally impounded by both adjoining insoluble strata and by less pure (usually thinly bedded) units within the carbonate sequence. 


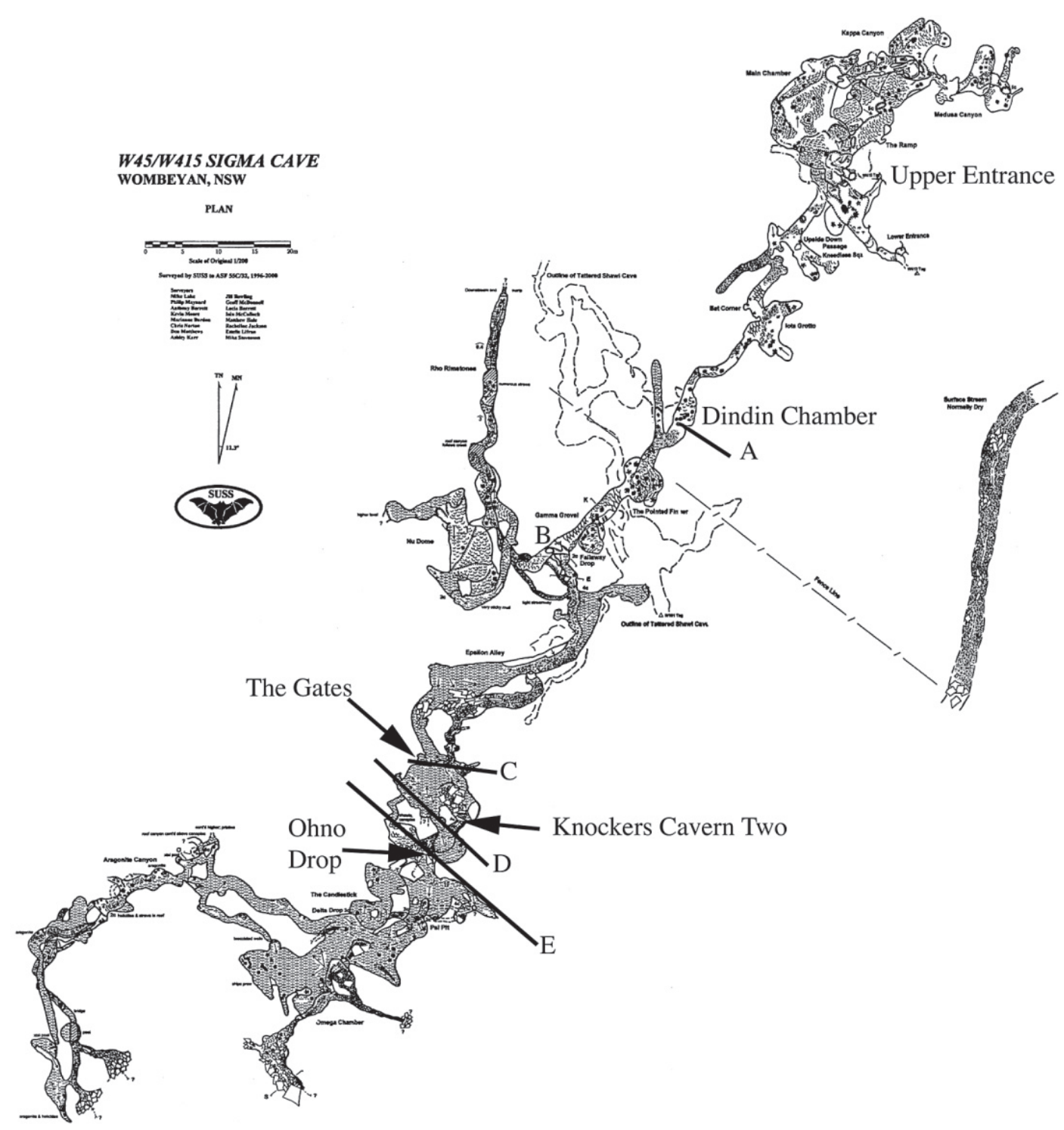

Fig. 6. Sigma Cave, Wombeyan, map courtesy of Sydney University Speleological Society. A = Breached volcaniclastic dyke partition, see Fig. 7; B = Portal through bedrock, see Fig. 13; C = Volcaniclastic dyke partition breached by vadose stream; $D=$ Breached volcaniclastic dyke with elongate (NE-SW trending) ceiling rift developed on its SE side; E = Volcaniclastic dyke partition, with small portal forming Ohno Drop at the southern end of Knockers Cavern Two.

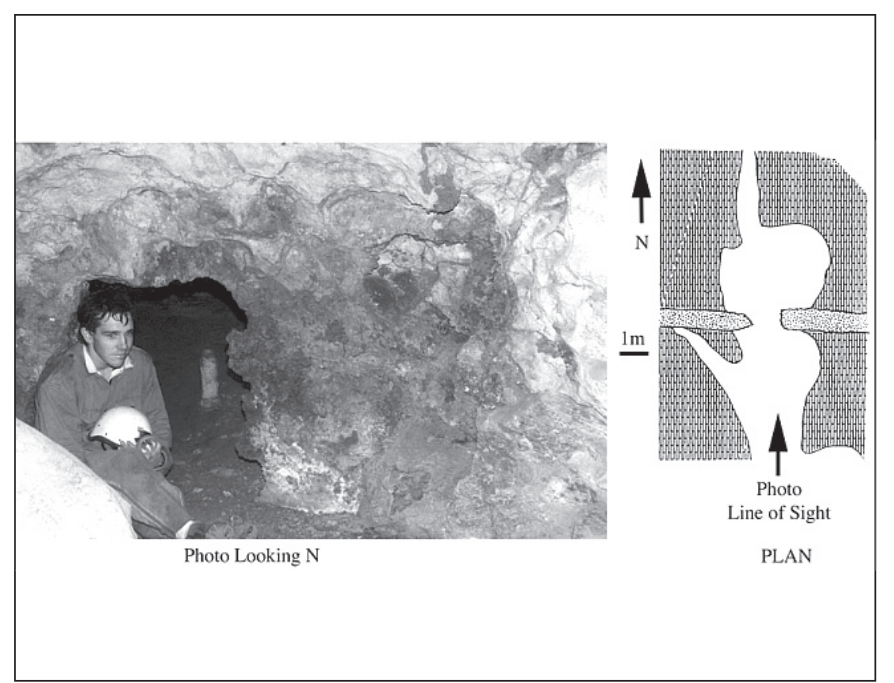

Fig. 7. Breached pyroclastic dyke partition, Sigma Cave, Wombeyan ("A" in Fig. 6). Weathered dyke is dark brown material to right of opening.

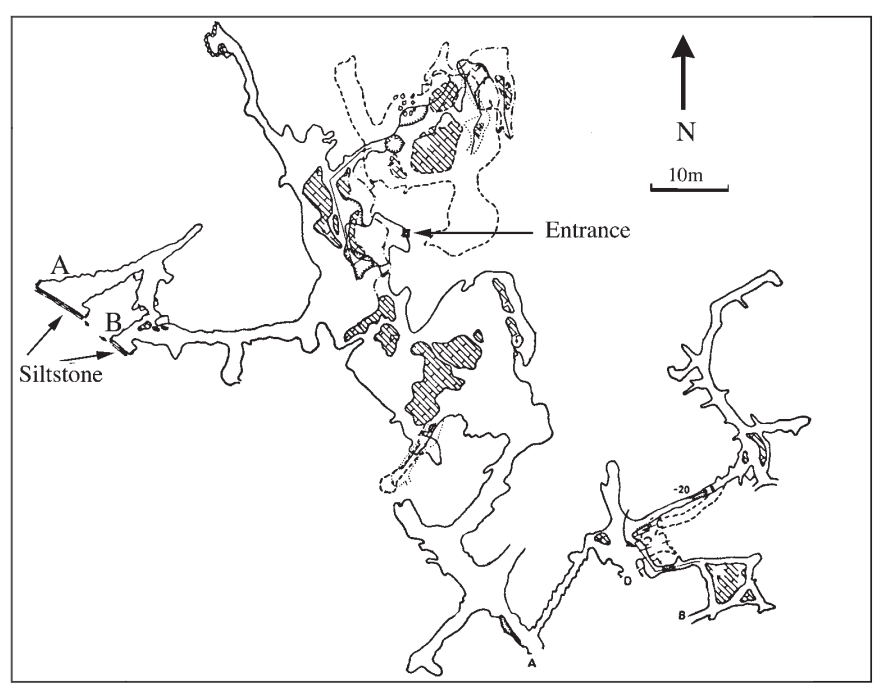

Fig. 8. Deep Hole, Walli, map after Frank (1974). A = northern hall terminated abruptly at contact with siltstone bed; $\mathrm{B}=$ southern hall terminated abruptly at contact with siltstone bed 


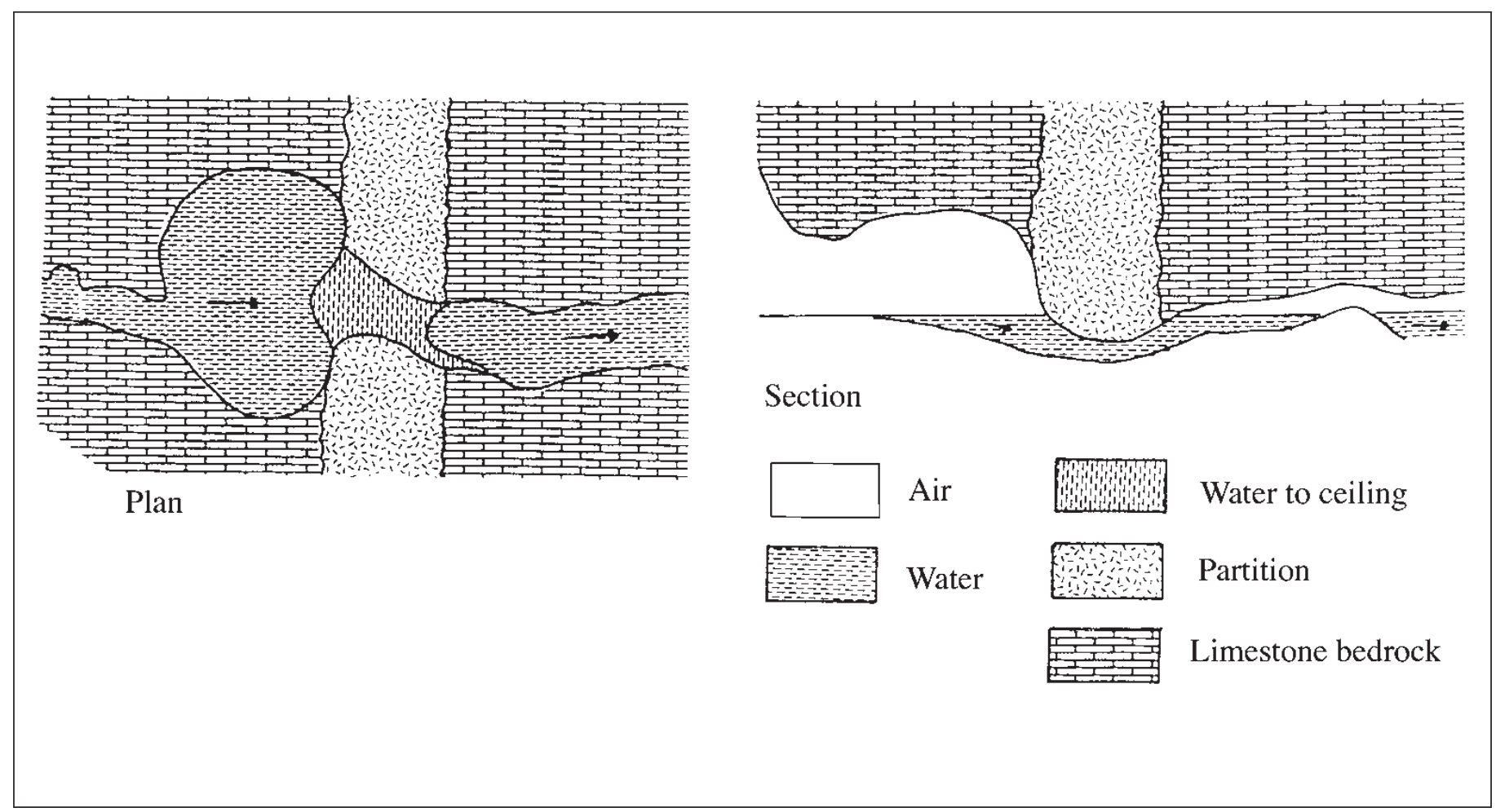

Fig. 9. Dolomitic palaeokarst body, acting as a partition (after Fig. 3 "C" of Osborne, 2000).

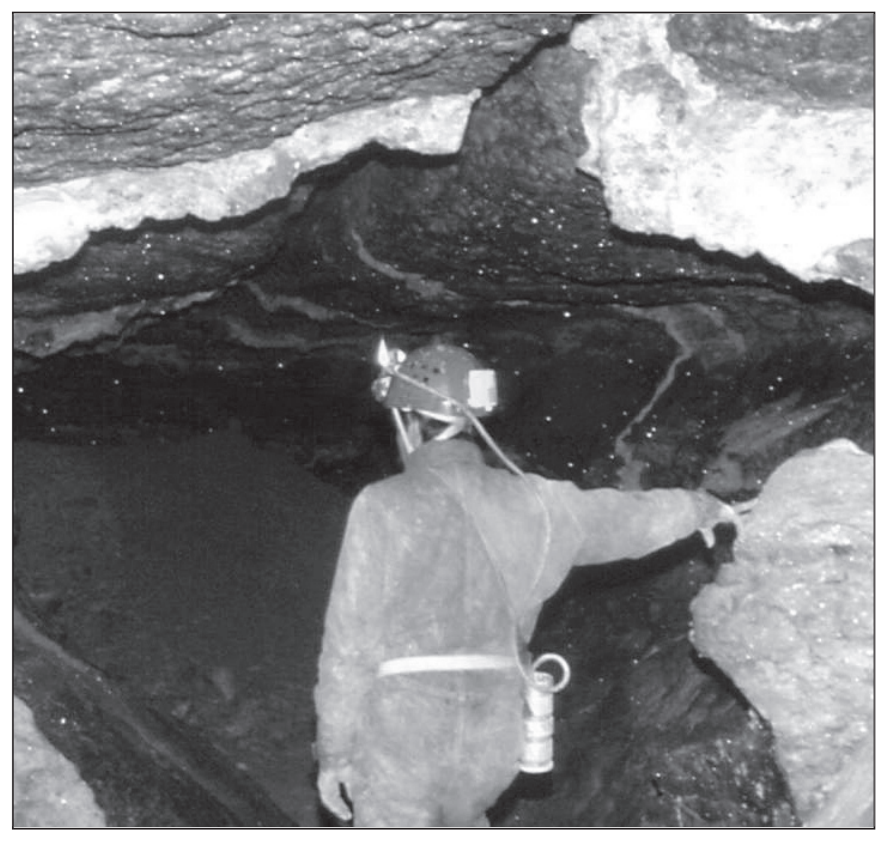

Fig. 10. Filling in pre-speleogenetic joint protruding into cave "passage". Mlynki Cave, western Ukraine. Note continuity of wall morphology on each side of the joint -fill.

Faults, more than other structures appear to have a dual role, acting both as barriers to speleogenesis and as groundwater sources. This is illustrated at Wellington Caves, New South Wales ("F" in Fig. 2) where cross-faults have acted to promote cave development while oblique faults have limited cave development by moving massive units against less soluble thinly bedded units (Osborne, 2001b).

\section{COMPARTMENTS}

Compartments are bodies of rock within a karst rock mass that are (or were) hydrologically isolated from adjoining similar bodies and/or the remainder of the karst rock mass as a whole by partitions. Compartments need not, however, be isolated from surface waters (except in confined artesian conditions) or from artesian or thermal waters. Thus both per descensum and per ascensum speleogenesis can occur within a compartment, but not between compartments while the partitions separating them remain intact.

From a speleogenetic viewpoint, compartments behave like micro impounded karsts and/or boundary karsts. Compartments are frequently impounded on two sides by partitions and on two other sides by the surrounding, impounding bedrock ("C1" in Fig. 1) but may be enclosed on all sides by partitions ("C 2 " in Fig. 1).

\section{PORTALS}

Portals are openings or "doorways" between cave voids that were not directly connected at the time when the voids were initially excavated. Portals thus permit hydrological connection and human access that would not have been possible prior to their opening. While portals that breach partitions are central to the argument in this paper, portals have also been observed that breach bedrock.

The processes described here assume that portals do not exist at the time of initial speleogenesis, but develop later. Partitions, particularly igneous dykes, are frequently not complete barriers and may contain "windows" of bedrock penetrating through them, while clastic dykes terminate with depth. Cave development through a window can be expected to produce a different 
final morphology than that produced by development of a portal. These differences are discussed below.

Most portals observed in caves were probably never hydrologically significant, having formed by vadose processes well above flowing water. From a speleogenetic point of view it is hydrological portals, breached by a combination of the weathering effect of epiphreatic water and hydraulic gradient, forcing water through pores and cracks and finally causing catastrophic failure, which are important.

\section{"Weathering" Portals Breaching Partitions}

Partitions will only function if they are resistant to failure under phreatic conditions. Deep phreatic waters whether of meteoric, artesian or thermal origins, tend to be less oxygenated than vadose waters and epiphreatic waters.

Basic dykes, volcaniclastic dykes, marine siltstones and dolomitic palaeokarst deposits frequently contain minerals (e.g. olivine and pyrite) that are unstable when exposed to oxidising vadose waters (seepage and stream) and slightly oxidising epiphreatic waters. This is particularly the case if the partitions have been altered by exposure to phreatic thermal waters.

Contact with vadose waters and to alternating inundation and exposure to air will result in weathering and failure of a partition, particularly if it has cave voids on both sides (Fig. 11), resulting in the opening of a portal.

In karsts such as Colong and Jenolan, with many partitions blocking stream flow along strike, partition failure may well have been a cascading process. However a significant amount of detailed work will

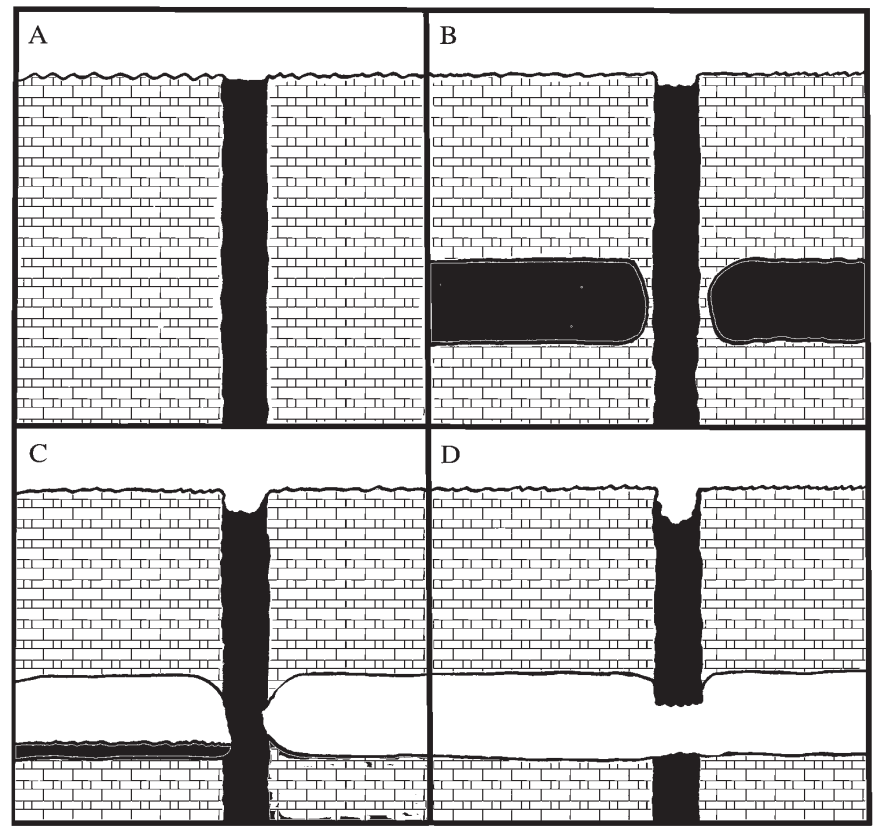

Fig. 11. Partition failure and portal formation due to vadose weathering. $A=$ Intact dyke penetrating massive limestone; $B=$ Dyke is approached on both sides by phreatic cavities; Dyke acts as a partition. $\mathrm{C}=$ Cavities enter vadose zone, aggressive vadose/ epiphreatic water in left cavity and subaerial weathering in both cavities partly destroys dyke; $D=$ Dyke is finally breached by vadose weathering, forming a portal. be required to piece together the history of portal formation in complex karsts such as these.

\section{Breakdown Portals}

Weathering of dykes is frequently a progenitor of cave breakdown by vadose weathering (Osborne, 2002). Thus under vadose conditions dyke partitions can fail, initiating breakdown of the surrounding bedrock (Fig. 12). While breakdown portals may have minimal speleogenetic significance, they frequently permit human access between compartments that would not otherwise be possible. In Colong Cave, despite decades of exploration, the only known means of access between the northern and southern sections of the cave (separated by a thick dyke partition) is through a breakdown portal in Amber Cave (Figs 4 \& 14).

Breakdown on a much smaller scale has the potential to open portals through insoluble bed partitions. This is currently happening in Deep Hole at Walli where the siltstone partitions at the end of the halls are breaking down through a combination of chip failure and crystal wedging by gypsum (Fig. 8). This failure extends for 1 $\mathrm{m}$ from the siltstone/limestone boundary at " $\mathrm{A}$ " and $0.5 \mathrm{~m}$ from the limestone boundary at "B".

Stratigraphic measurements by Percival (1976) indicated that this siltstone bed is $4.5 \mathrm{~m}$ thick and has limestone stratigraphically both above and below it. Deep Hole is developed in limestone stratigraphically below the siltstone bed.

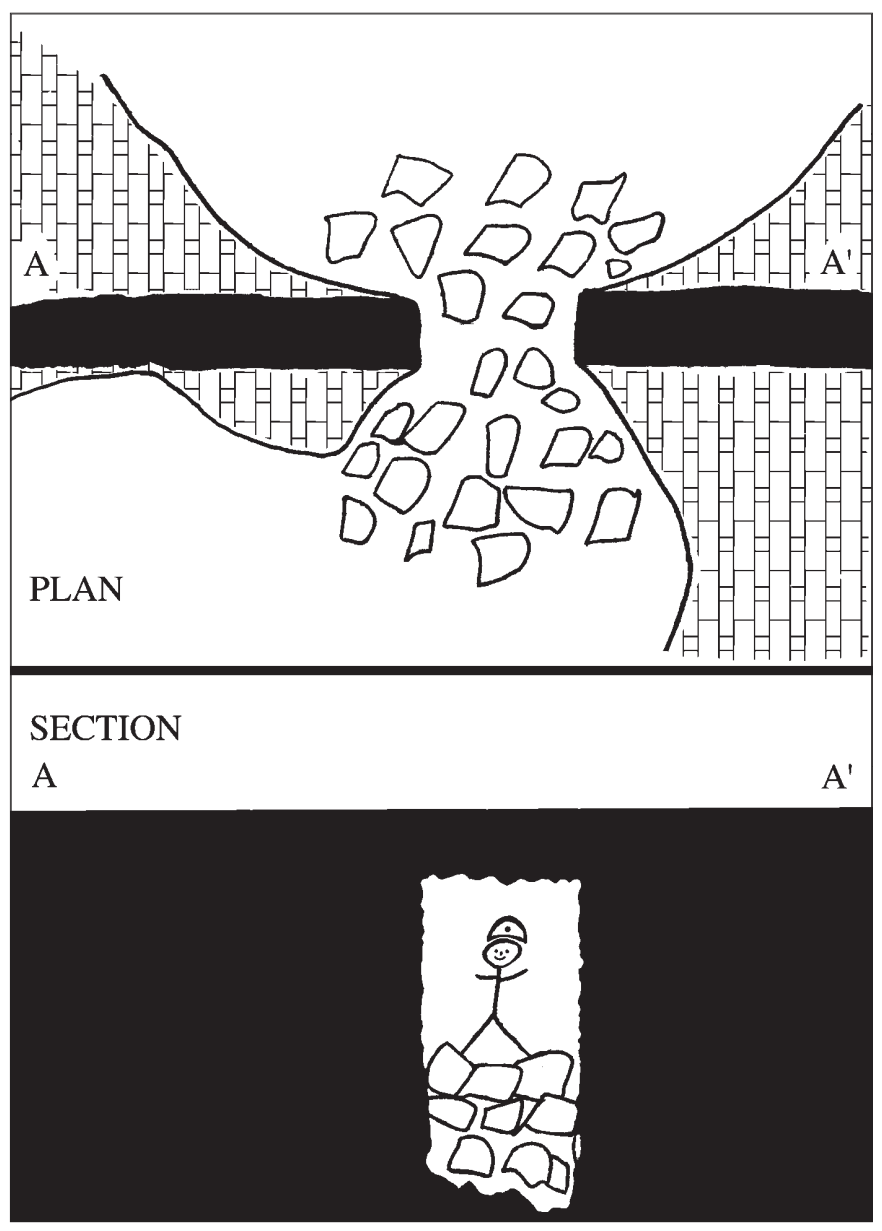

Fig. 12. A breakdown portal, based on Amber Cave, Lannigan's Cave, Colong. 


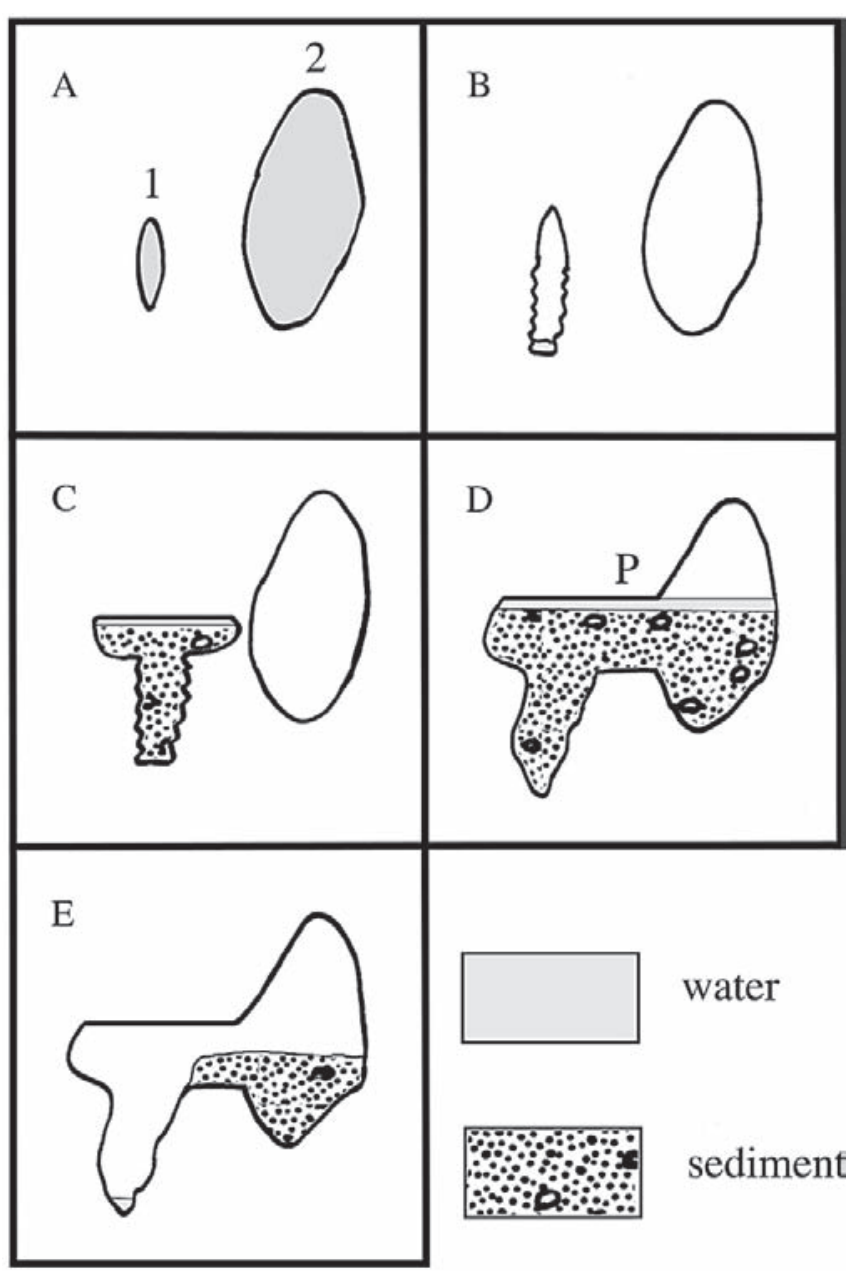

Fig. 13. Opening of a portal through bedrock by paragenesis. Based on observations in Sigma Cave, Wombeyan. A = Two phreatic voids, "1" and "2" are situated adjacent to one another, but have no direct connection; B = A vadose stream invades void "1", resulting in canyon formation; C = The stream in "1" becomes choked with sediment, resulting in paragenesis; $D=A$ paragenetic notch erodes laterally above the sediment fill and breaches the wall of void " 2 ", forming portal "P"; E = Sediment responsible for paragenesis largely removed, resulting in present situation.

\section{Portals Breaching Bedrock}

While the concept of a portal has been introduced here in the context of partitions, portals can occur which do not breach partitions, but rather make late stage connections through bedrock separating sections of cave with unrelated origins. This type of portal is much more difficult to recognise than one breaching a partition.

Both invading vadose streams and paragenesis can open portals through bedrock between previously separated cavities. These portals are not as significant for speleogenesis as portals breaching partitions however they do permit atmospheric and biotic exchange, as well as human access, between initially isolated cavities.

The development of a portal through bedrock by paragenesis, based on observations in Sigma Cave, Wombeyan, is illustrated in Fig. 13. This portal could easily be misinterpreted as a primary connection between void " 1 " and " 2 ".

\section{Windows Vs Portals}

Original holes in dykes (windows), particularly if they are aligned with "inception horizons" or "productive beds" in the limestone would allow "normal" per descensum meteoric cave passage development to proceed through an otherwise impenetrable barrier. In such cases the remainder of the dyke would be expected to act as a dam, resulting in a widening of the passage upstream of the barrier and a narrowing downstream. Klimchouk et al. (1995) noted that in the case of their pre-speleogenetic joint fillings there was no change in passage morphology on either side of the fillings.

In some cases described here the cave morphology on either side of the partition is different, not as a result of damming or throttling by the portal, but because the portal connects cave voids with differing speleogenetic histories.

\section{Further thoughts on Portal Opening}

The discussion that follows assumes that it is possible for coincident cave voids to develop on either side of unbreached hydrological barriers. In the case of voids developed along bedding this is explained by the cavities developing in the same "inception horizon' or "productive bed". In the case of gypsum caves the cavities develop along the same major joint.

The complexity of the relationships between cave voids and partitions can be seen in Fig. 14. The Passage of Dykes is a short circular tube, $6 \mathrm{~m}$ long and $1.5 \mathrm{~m}$ in diameter. It penetrates one thick dyke and at least four thinner dykes. One possible explanation for this remarkable penetration is that a joint that formed after the dykes were emplaced guided development of this passage.

\section{SPELEOGENESIS PRIOR TO PORTAL OPENING}

Fig. 1 shows an impounded karst with steeply dipping beds and partitions oriented perpendicular and oblique to strike. Integrated cave development along the length of the rock mass is impossible while these partitions remain intact. In this situation a meteoric stream cave, for instance, would not be able to form along strike.

Two types of speleogenesis are possible while the partitions remain intact:

- $\quad$ per ascensum longitudinal, lateral or network speleogenesis

- Lateral meteoric speleogenesis

Per ascensum longitudinal, lateral or network speleogenesis

Rising water may enter the compartments from depth, but will not breach them within the zone of speleogenesis. Depending on the "openness" of beds and joints the rising waters may dissolve longitudinally along bedding, laterally along joints or along both producing a network cave. This speleogenesis will be impounded laterally by the insoluble rocks impounding the karst as a whole (or by oblique 

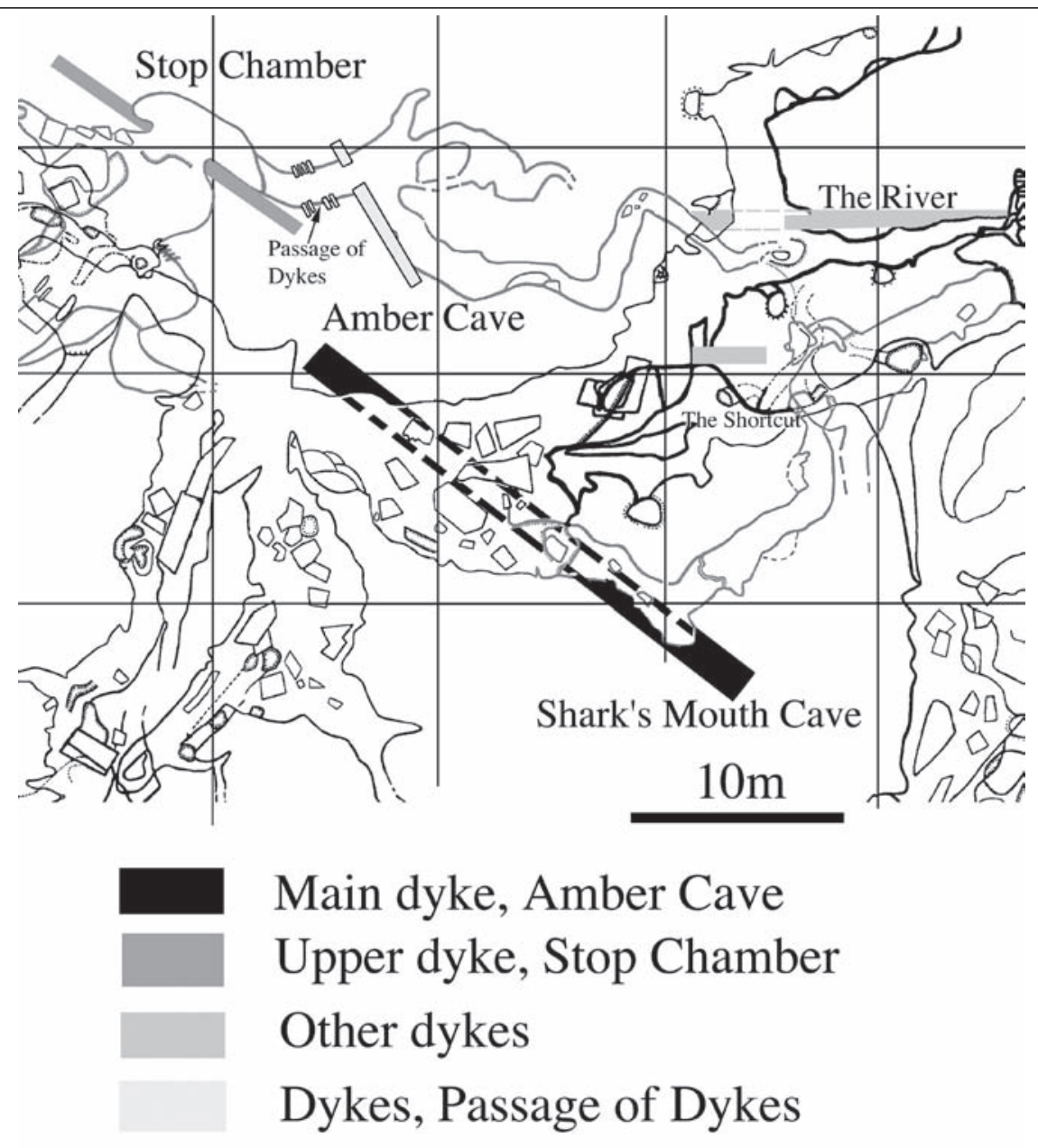

Fig. 14. Amber Cave region, Lannigan's Cave, Colong Caves, detail from unpublished mapping by Alan Pryke, showing dykes, upper level passages in grey. The Upper dyke in Stop Chamber and the Main dyke in Amber Cave are probably the same dyke. There is likely to be some distortion of the survey due to the magnetic properties of the dykes.

Note: Penetration of Passage of Dykes through one thick and at least 4 thin dykes. Development of The River and the passage next to Passage of Dykes beside dykes.

partitions) and along strike (longitudinally) by the transverse partitions (Fig. 15).

Where they are blocked by partitions the cavities (which are "halls" in the sense of Osborne, 2001a) have been observed to behave in a number of ways. In some cases they will stop "dead" without any change in diameter or morphology. They may widen to form a chamber, penetrate as tubes along the side of the partition, expand upwards to form a large blind cupola or expand upwards forming a smaller, upwardnarrowing "outlet" cupola.

Per ascensum caves formed within a compartment may become open to the surface; by surface lowering of the limestone, through erosion and cliff retreat along lateral streams by opening of their outlet cupolas, or by vadose invasion (Osborne, 1999a).

\section{Lateral meteoric speleogenesis}

Lateral meteoric speleogenesis occurs when water sinks on one margin of an impounded karst and rises on the other margin, or into a lateral valley running close to the other boundary of the karst (Fig. 16). Lateral meteoric speleogenesis thus produces a special form of boundary karst.

In Fig. 16 the stream S1-R1 has penetrated through the limestone mass along the space previously occupied by a dyke. This could result in a cave, or later develop into an open canyon as at "B". Stream S2-R2 has been captured underground along a joint and exits at the other side of the limestone mass into the marginal stream "A". Because this is within a compartment sealed along strike by dykes the cave is unlikely to develop along strike to any extent. Stream S3-R3 has entered the limestone along a cross joint and then excavated along strike (and down gradient) to rise into the crosscutting stream in the canyon "B". Development along strike is possible in this case, as there are no inhibiting partitions.

\section{SPELEOGENESIS AFTER PORTAL OPENING}

Even when portals have breached partitions, the path for cave development along strike is by no means simple or direct. Streams passing through portals will encounter a complex of pre-existing cavities in each new compartment they enter. Some pre-existing cavities will be of per-ascensum origin and others will 


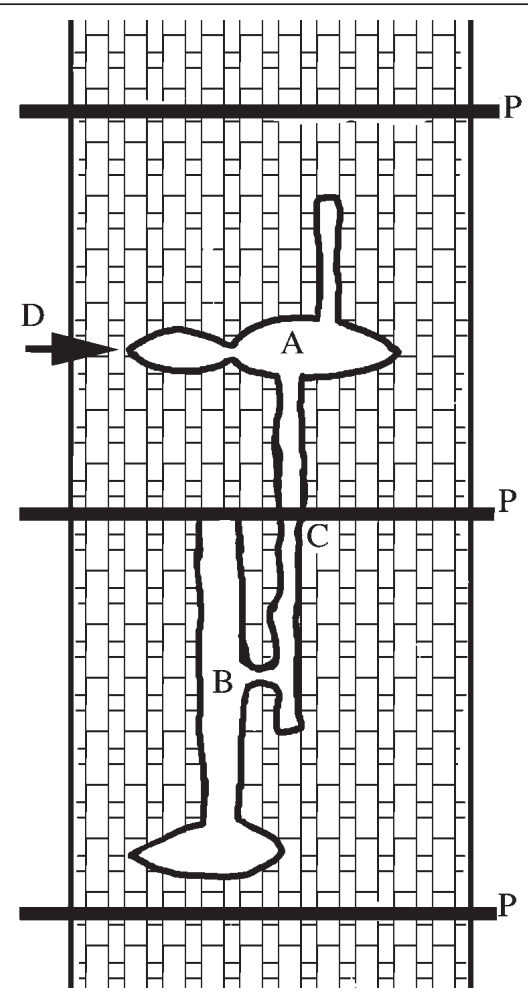

Fig. 15. Per ascensum longitudinal, lateral or network speleogenesis in steeply dipping limestone, plan view.

$A=$ Cupola developed along vertical joint with strike perpendicular to bedding; $\mathrm{B}=$ Hall developed along strike and terminated by partition; $\mathrm{C}=$ Halls developed along same bed blocked by partition. Breaching of partition would produce a situation similar to that illustrated in Fig. 11; $\mathrm{D}=$ Point where lateral meteoric speleogenesis could begin by invasion along joint that guided initial cupola development. $\mathrm{P}=$ Partitions.

have a lateral meteoric origin. While some pre-existing cavities will be developed along strike, the geometry of the pre-existing voids will not necessarily be conducive to direct passage of water along strike.

Similarly, portals will occur where the partitions are most easily breached, not where they will provide the best access to potential flow paths in the downgradient compartment(s). As I observed at Bungonia, Colong and Jenolan, "the path of these streams and the passages in which they flow are neither simple nor continuous" (Osborne, 1999b, p. 6).

At Colong and Jenolan the partitions have been substantially breached, allowing the development of major along-strike underground streams. In the case of Lannigan's Cave at Colong the route of the main stream through approximately 180 metres strike length of limestone, where it crosses the main dyke zone, remains completely unknown. At Jenolan the Jenolan Underground River breaches a combination of igneous dyke, pyroclastic dyke and dolomitic palaeokarst partitions in its complex path.

At Bungonia many dyke partitions appear to be completely intact or to have remained intact at some levels in the limestone mass and been breached at other levels (usually lower). Thus the hydrology

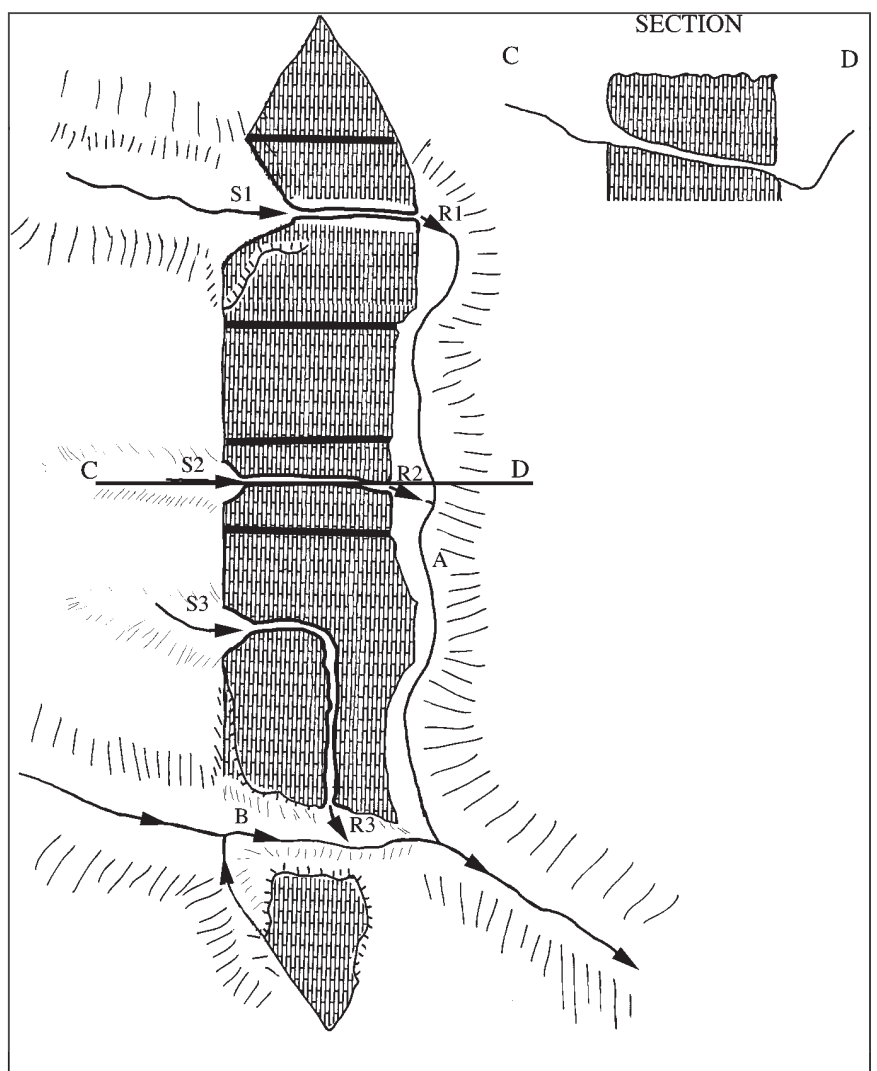

Fig. 16. Lateral Meteoric Speleogenesis, diagram modified after Osborne (1999a) Fig.14. A = Marginal valley; $B=$ Stream flowing in canyon through limestone outcrop; $C-D=$ Section through limestone along joint; S1, S2 \& S3 = Sinks; R1, R2 \& R3 = Resurgences. Per ascensum longitudinal, lateral or network speleogenesis and lateral meteoric speleogenesis are by no means mutually exclusive. There is evidence that both processes have occurred, probably sequentially, in both Lannigan's Cave at Colong and at Jenolan Caves.

at Bungonia is more complex and the caves less integrated than at Colong and Jenolan (see James et al. 1978 and Osborne 1993a).

Continued vadose weathering of partitions following their initial breaching can result in breakdown, and in the formation of large breakdown portals. Weathering of dykes is an important trigger for breakdown, particularly at Colong (Osborne, 2002).

\section{CONCLUSIONS}

It is unlikely that per descensum meteoric speleogenesis will be able to penetrate insoluble barriers oriented perpendicular or oblique to bedding in bodies of vertical to steeply dipping limestone. It is more likely that cavities formed on either side of the barriers by a per ascensum (artesian, hydrothermal or thermal) mechanism and that the barriers failed later. Some meteoric penetration may occur if the cave is guided by joints that post-date emplacement of the dykes, however voids guided by such joints could also form by per ascensum processes.

Where complex caves are developed in Palaeozoic limestones dating the penetrated dykes would set a maximum age for cave development as the dykes were clearly emplaced before the caves formed. The extreme 
alteration of the dykes makes this difficult, however $\mathrm{K}$-Ar feldspar dating may be possible on some of the less-weathered dykes. K-Ar illite dating may in some cases give a date for the commencement of weathering, possibly indicating entry into the vadose zone.

Recognition of partitions and portals, particularly breakdown portals, is essential for the interpretation of the speleogenetic history of caves in which they occur. It is far too easy to assume that the route humans use to travel through a cave has some genetic significance. Where the route passes through portals it became opened only very recently in the history of the cave and is unrelated to the caves early or primary development.

\section{ACKNOWLEDGEMENTS}

The author would like to thank Alan Pryke for his keen eye for dykes and for making his unpublished maps of Lannigan's Cave available. The Jenolan Caves Reserve Trust is thanked for permission to undertake fieldwork at Jenolan and Wombeyan Caves. The National Parks and Wildlife Service of New South Wales is thanked for permission to undertake fieldwork to Bungonia and Colong Caves and Sydney Speleological Society is thanked for access to Walli Caves.

Jill Rowling, Alan Pryke, Peter Wellings and members of Sydney University Speleological Society and Sydney Speleological Society are thanked for their assistance in the field.

Alexander Klimchouk is thanked for his hospitality and assistance during the author's visit to the Ukraine in 2001, and for providing bibliographic information. P.J. Osborne assisted by reading and checking the drafts.

\section{REFERENCES}

Bauer, J. \& Bauer P., 1998 - Under Bungonia. J.B. Books, Oak Flats.

Frank, R.M., 1974 - Sedimentary development of the Walli Caves, New South Wales. Helictite 12, 3-30.

James, J.M., Francis, G. \& Jennings, J.N., 1978 Bungonia Caves and Gorge; a new view of their geology and geomorphology. Helictite 16 (2): 53-63.

Klimchouk, A.B., Andrejchouk, V.N. \& Turchinov, I.I., 1995 - Structural prerequisites of speleogenesis in gypsum in the Western Ukraine. Ukrainian Speleological Association, Kiev, 106 p. (Russian \& English).

Osborne, R.A.L., 1985 - Letter, Dykes and cave development at Colong Caves, New South Wales. Helictite 23(1): 33-35.

Osborne, R.A.L., 1993a - A new history of cave development at Bungonia, N.S.W. Australian Geographer 24(1): 62-74.

Osborne, R.A.L., 1993b - The history of karstification at Wombeyan Caves, New South Wales, Australia, as revealed by palaeokarst deposits. Cave Science 20(1): 1-8.

Osborne, R.A.L., 1993c - Geological Note: Cave formation by exhumation of Palaeozoic palaeokarst deposits at Jenolan Caves, New South Wales. Australian Journal of Earth Sciences 40: 591-593.

Osborne, R.A.L., 1999a - The inception horizon hypothesis in vertical to steeply dipping limestone: applications in New South Wales, Australia. Cave and Karst Science 26(1): 5-12.

Osborne, R.A.L., 1999b - The origin of Jenolan Caves: Elements of a new synthesis and framework chronology. Proceedings of the Linnean Society of New South Wales.121: 1-26.

Osborne, R.A.L, 2000 - Paleokarst and its Significance for Speleogenesis, in Klimchouk, A.B., Ford, D.C., Palmer, A.N., and Dreybrodt, W., Eds. Speleogenesis, Evolution of Karst Aquifers: Huntsville, National Speleological Society, p. 113-123.

Osborne, R.A.L., 2001a - Halls and narrows: Network caves in dipping limestone, examples from eastern Australia. Cave and Karst Science 28 (1), 3-14.

Osborne, R.A.L., 2001b - Karst geology of Wellington Caves: a review. Helictite 37 (1), 3-12.

Osborne, R.A.L., 2001c - Cave Breakdown by Vadose Weathering. International Journal of Speleology 31(1-4): 37-53.

Percival, I.G., 1976 - The geology of the Licking Hole Creek Area, near Walli, Central Western New South Wales. Journal and Proceedings of the Royal Society of New South Wales 109: 7-23.

Lauritzen, S-E., 2001 - Marble stripe karst of the Scandinavian Caledonides: an end-member in the contact karst spectrum. Acta carsologica 30 (2): 47-79.

Webby, B.D. \& Packham, G.H., 1982 - Stratigraphy and regional setting of the Cliefden Caves Limestone Group (Late Ordovician), central-western New South Wales. Journal of the Geological Society of Australia 29, 297-317. 